\title{
Monitoring the water quality of Jiu River in Dolj County
}

\author{
Florin Faur ${ }^{1}$, Maria Lazăr ${ }^{1}$, Izabela-Maria Apostu ${ }^{1, *}$, Oleg Pinchuk ${ }^{2}$, and Serhii Klimov ${ }^{2}$ \\ ${ }^{1}$ University of Petrosani, Faculty of Mining, Department of Environmental Engineering and Geology, 332006, Petrosani, Romania \\ ${ }^{2}$ National University of Water and Environmental Engineering, Department of Hydroinformatics, 33028, Rivne, Ukraine
}

\begin{abstract}
Water is a renewable natural resource, but vulnerable and limited in terms of quantity and quality, which is why its exploitation must be done rationally, so as to ensure a complex recovery and a balanced distribution, depending on needs. The water management activity, which has as object the establishment and application of measures for rational use and control of water resources, quantitative and qualitative, is closely related to meeting the requirements of current legislation on exploitation and protection of water and aquatic ecosystems. In this context, the present paper presents a study carried out during 2019 , having as the main objective the qualitative characterization of the Jiu River on the administrative territory of Dolj County (Romania). For this purpose, several water sampling campaigns (12, one for each month) from three control sections, established in partnership with the Jiu - Craiova Water Basin Administration, were carried out. The collected samples were analyzed in the analytical laboratory of the same institution and, on the basis of the obtained results, also considering the main existing sources of pollution, conclusions were drawn regarding the Jiu River water quality in the analyzed sector. Also, we applied an alternative control method whose purpose was to validate the initial conclusions.
\end{abstract}

\section{Introduction}

The central objective of the European Water Framework Directive is to achieve a "good status" for all bodies of water, both surface and underground, with the exception of heavily modified and artificial bodies, for which the goal is to achieve a "good ecological potential" [1]. Based on the principles contained in this directive, at the level of the Jiu - Craiova Water Basin Administration, a management plan is under development, a plan that has to solve the main problems related to water management, both quantitatively and qualitatively. Water management must provide solutions to ensure the current and future water needs of the population and the economy, starting from the renewable but limiting nature of freshwater resources [2].

For the sustainable management of water resources, the international community recommends that governments apply the following principles [3-5]:

1. The basin principle. Water resources are formed and managed on river basins. Rational management of water resources requires a global approach, combining social issues and economic development with the protection of natural ecosystems. Sustainable management of water resources can only be achieved at the level of the entire river basin, by taking into account all water users.

2. The principle of unitary quantity-quality management. The two sides of water management being in a close connection, it appears necessary a unitary approach, leading to optimal technical and economic solutions for both aspects.
3. The principle of solidarity. Planning and development of water resources requires the collaboration of all factors involved in the water sector: the state, local communities, users, water households, etc.

4. The "polluter pays" principle. All expenses related to water and environmental pollution, implicitly those of removing the effects and restoring the previous conditions, are borne by the one who produced the pollution.

5. The economic principle "the beneficiary pays". Water has an economic value in all its forms of uses and must be recognized as an economic good. Managing water as an economic good is an important way to achieve efficient and equitable exploitation and to preserve and protect water resources.

These principles underpin the concept of integrated water management, which combines the problems of water use with those of protection of natural ecosystems [5].

Sustainable management of water resources, especially from a qualitative point of view, takes into account a number of objectives [3,4], among which we mention:

- Ensuring the continuous supply of water with adequate quality of uses and, in particular, of the population requirements;

- Refurbishment of production processes by using clean, non-polluting technologies;

- Construction of new treatment plants and modernization of existing ones, in order to reduce pollutants discharged into surface waters and/or groundwater;

\footnotetext{
* Corresponding author: izabelamaria.nyari@yahoo.com
} 
- Elaboration of a normative framework necessary for the creation of hydrological and hydrogeological reserves, in order to protect vulnerable basins and aquifers;

- Implementation of methods and means to prevent, limit and reduce the effects of accidental pollution;

- Improving education for a clean aquatic environment;

- Improvement and creation of habitats corresponding to biodiversity conservation;

- Ensuring appropriate flows on watercourses, in order to protect aquatic ecosystems;

- Ensuring the continuity of the flow on the watercourses, in order to facilitate the migration of the fish species.

\section{Description of the studied area}

Jiu H.B. (hydrographic basin) has a length of approx. 260 $\mathrm{km}$ and an average width at the top of approx. $60 \mathrm{~km}$ and approx. $20 \mathrm{~km}$ at the bottom (figure 1).

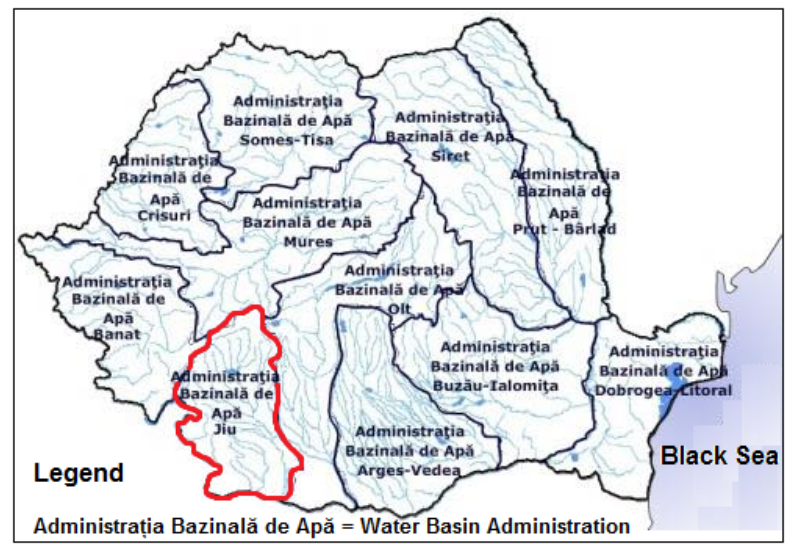

Fig. 1. Delimitation of hydrographic basins in Romania [6].

A feature of Jiu H.B. is the elongated form. The hydrographic network has a length of $3,876 \mathrm{~km}$ and a density of $0.34 \mathrm{~km} / \mathrm{km}^{2}$ [7].

The average altitude of the Jiu H.B. varies between $1,649 \mathrm{~m}$ in the northern area and $24.1 \mathrm{~m}$ in the confluence area. The average slope of the basin is of 5\%o [8].

On the right side, Jiu River, receives 31 tributaries (of which the most important: Tismana, Jilt, Motru and Raznic), while from the left side it receives 21 tributaries (of which the most important: Sadu, Cioiana, Gilort and Amaradia) [9].

The complex geological composition and the differentiated action of the climatic factors contributed to the formation of a wide variety of relief forms: mountains, hills, plains and swamps. These units are distributed in broad areas whose altitude declines from north to south (figure 2).

In relation to the altitude, more than $21 \%$ of the area, namely the northern and the northwestern parts, are occupied by mountain areas. The hills, belonging to the Getic Plateau and the Mehedinţi Plateau, occupy about $47 \%$, the plain area being of over $32 \%$ [2].

The mountainous region has different characters due to the complex geological and lithological structure and determines a proper distribution of all elements of the natural environment (climate, vegetation, soils, etc.)

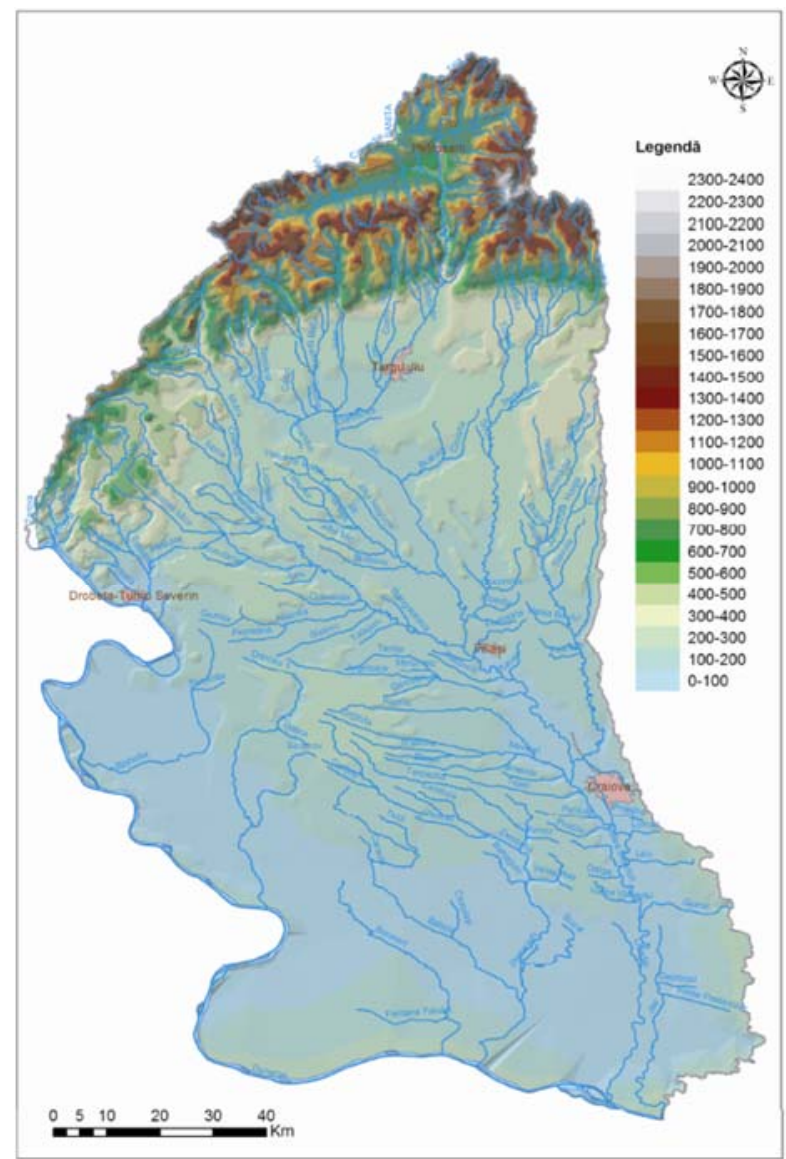

Fig. 2. Morphology of Jiu H.B. [7].

Subcarpathian depression includes:

- The depression of Celei - Novaci;

- Subcarpathian hills;

- Intercolinary depression Câlnic - Tg. Jiu - Câmpu Mare - Tg. Cărbuneşti;

- The piedmont hills in the south.

The piedmont area is represented by the Mehedinţi Plateau, located immediately in the south-east of Mehedinţi Mountains and represents a geographical individuality, although it is an organic continuation of the respective mountains.

The Getic Plateau is a large morphological unit extending south of the sub-Carpathian area up to the northern limit of the plain.

Oltenia Plain as a morphological subunit of the Romanian Plain is located in the south and southwest of the analyzed area, being delimited by the Danube and Olt rivers. As genesis and evolution, the Oltenia Plain is exclusively a creation of the Danube, the predominant forms of the relief being represented by the Danube meadow and terraces, the Jiu valley, to which the plain is added and, as a specific note, the relief of dunes.

The geological deposits that appear at the surface are of Miocene, Pliocene and Quaternary age, predominant being the siliceous type of rocks. The limestone rocks appear on limited areas, in the mountainous area, as well as in the northern part of the Bahna and Topolnița subbasins. 


\section{Material and methods}

\subsection{Pollution sources}

In line with the Water Framework Directive, significant pressures are considered to be those that result in the failure to meet environmental objectives for the studied water body. Depending on how the body of water is operating, we can know if a pressure can cause an impact $[10,11]$. Thus, in the present study, 4 major categories of problems were identified: pollution with organic substances, pollution with nutrients, pollution with priority and/or dangerous substances and hydromorphological alterations, described below:

\section{Point sources of significant pollution}

1. Urban pollution sources/human agglomerations

Urban wastewater contains, in particular, suspended matter, organic substances, nutrients, but also other pollutants such as heavy metals, detergents, petroleum hydrocarbons, organic micropollutants, etc. [2].

The industrial wastewaters similar to those from urban sources, contains the same pollutants but in different proportions, depending on the types of industry, as well as the pre-treatment level of the industrial waters collected in the sewer system (figure 3).

In terms of pollutants releases into surface water resources, table 1 show the monitored average quantities.

The organic substances are expressed as $\mathrm{CCO}-\mathrm{Cr}$ and $\mathrm{CBO}_{5}$, while the nutrients as total nitrogen and total phosphorus (data between 2014 and 2017 per categories of agglomerations).

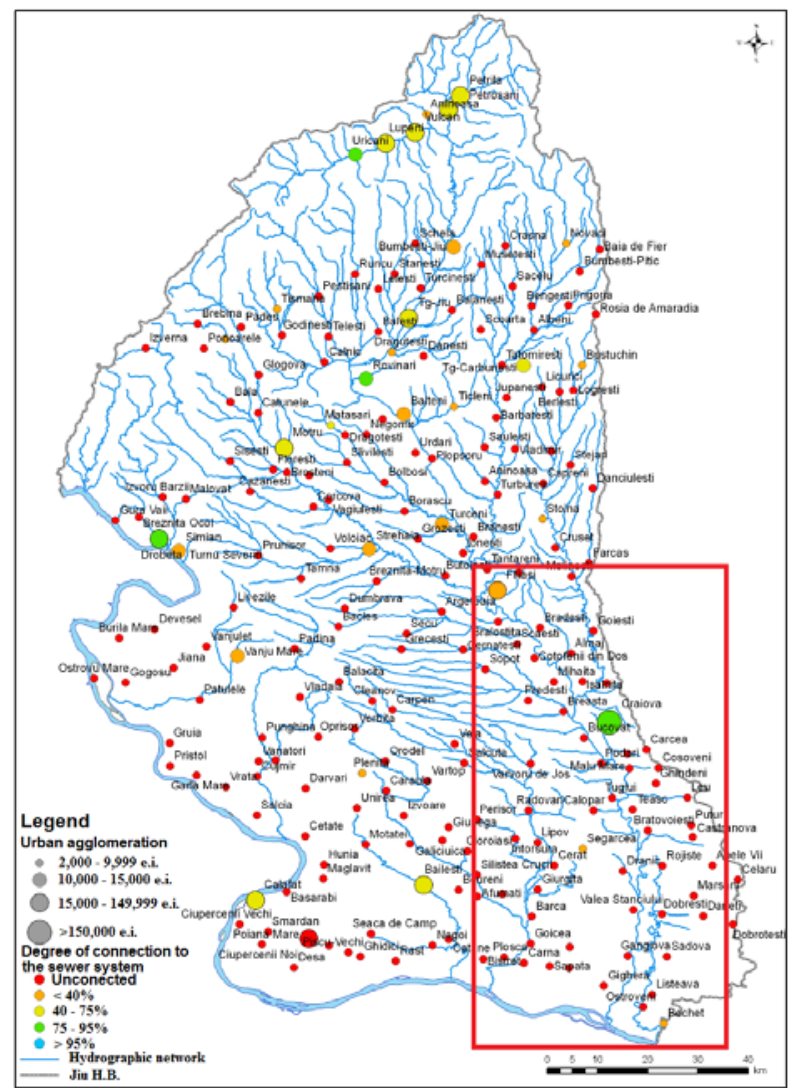

Fig. 3. Urban point sources of pollution (domestic and similar wastewaters) [7] (modified).

Table 1. Average discharges of organic substances and nutrients from human agglomerations into Jiu River [7].

\begin{tabular}{|c|c|c|c|c|}
\hline $\begin{array}{c}\text { Number of inhabitants } \\
\text { (equivalent inhabitants) }\end{array}$ & $\begin{array}{c}\text { Organic substances } \\
\text { (CCO-Cr) }\end{array}$ & $\begin{array}{c}\text { Organic substances } \\
\text { (CBO5) }\end{array}$ & N total & P total \\
\cline { 2 - 5 } & $\mathrm{t} /$ year & $\mathrm{t} /$ year & $\mathrm{t} / \mathrm{year}$ & $\mathrm{t} /$ year \\
\hline$>100.000$ & 8061.424 & 3428.233 & 1836.405 & 868.688 \\
\hline $10.000-100.000$ & 1166.029 & 569.761 & 217.800 & 18.318 \\
\hline $2.000-10.000$ & 63.298 & 38.247 & 14.801 & 1.494 \\
\hline$<2.000$ & - & - & - & - \\
\hline Total & 9290.751 & 4036.241 & 2069.006 & 888.500 \\
\hline
\end{tabular}

\section{Sources of industrial and agricultural pollution}

Sources of industrial and agricultural pollution contribute to the degradation of water resources by evacuating pollutants specific to the type of activity carried out (organic substances and nutrients: food industry, chemical industry, fertilizer industry, pulp and paper, livestock farms, etc.; heavy metals: extractive and processing industries, chemical industry, etc.; dangerous organic micropollutants: organic chemical industry, petroleum industry, etc.) [7] (figure 4).

The most important and significant point sources of industrial and agricultural pollution identified in the studied area are:

- C.S. Craiova Energetic Complex - Işalniţa Electric Power Plant;

- C.S. Craiova Energetic Complex - Craiova II Electrocentrale Branch;

- C.S. Automotive Subassemblies Craiova S.A.;
- C.S. Eco Sud Ltd.;

- C.S. Zahărul S.A. Podari;

- Petrom S.A. - Member of OMV Group. Petrom Craiova - DOLJCHIM Craiova;

- Leamna Pneumoftiziology Hospital;

- C.S. FELVIO Ltd. Bucovăţ (chicken intensive growth);

- A.N.P.- Pelendava Craiova Penitentiary (agriculture, zootechny, meat and milk processing);

- C.S. GIM CO Ltd. (chicken intensive growth);

- Sadova Socio - medical Facility;

In terms of releases of pollutants into surface water resources, table 2 shows the monitored average quantities of organic substances (expressed as $\mathrm{CCO}-\mathrm{Cr}$ and $\mathrm{CBO}_{5}$ ) and nutrients (total nitrogen and total phosphorus) between 2014 and 2017 per categories of pollution sources. Table 3 also shows the same situation, given the quantities of heavy metals measured and monitored. 

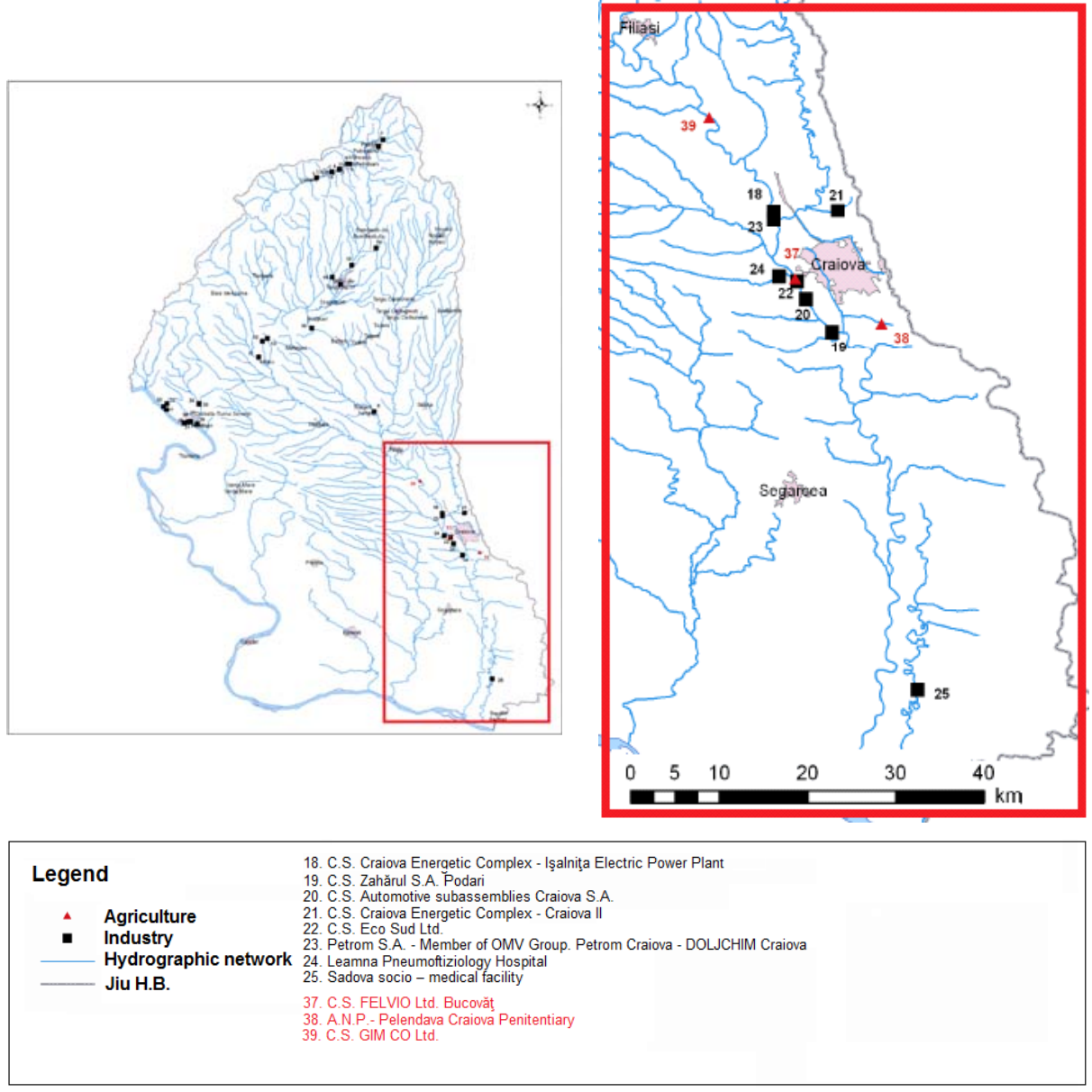

Fig. 4. Industrial and agricultural point sources of pollution [7] (modified).

Table 2. Average discharges of organic substances and nutrients from industrial and agricultural point sources into Jiu River [7].

\begin{tabular}{|c|c|c|c|c|}
\hline \multirow{2}{*}{ Type of industry } & $\begin{array}{c}\text { Organic substances } \\
\text { (CCO-Cr) }\end{array}$ & Organic substances (CBO5) & N total & P total \\
\cline { 2 - 5 } & $\mathrm{t} /$ year & $\mathrm{t} /$ year & $\mathrm{t} /$ year & $\mathrm{t} /$ year \\
\hline 'IPPC Industry & 12933.143 & 1904.359 & 31.389 & 12.831 \\
\hline Non 'IPPC Industry & 1313.617 & 321.987 & 16.295 & 26.009 \\
\hline Total Industry & 14246.760 & 2226.346 & 47.684 & 38.84 \\
\hline Other Sources & 170.997 & 8.606 & 8.509 & 0.056 \\
\hline
\end{tabular}

Table 3. Average discharges of heavy metals from industrial and agricultural point sources into Jiu River [7].

\begin{tabular}{|c|c|c|c|c|c|c|c|}
\hline \multirow{2}{*}{ Type of industry } & $\mathbf{C u}$ & $\mathbf{Z n}$ & $\mathbf{C d}$ & $\mathbf{N i}$ & $\mathbf{P b}$ & $\mathbf{H g}$ & $\mathbf{C r}$ \\
\cline { 2 - 8 } & $\mathrm{kg} / \mathrm{year}$ & $\mathrm{kg} / \mathrm{year}$ & $\mathrm{kg} / \mathrm{year}$ & $\mathrm{kg} / \mathrm{year}$ & $\mathrm{kg} / \mathrm{year}$ & $\mathrm{kg} / \mathrm{year}$ & $\mathrm{kg} / \mathrm{year}$ \\
\hline 'IPPC Industry & - & - & - & - & - & - & - \\
\hline Non 'IPPC Industry & 0.9 & 1.9 & - & - & 0.1 & - & 0.1 \\
\hline Total Industry & 0.9 & 1.9 & - & - & 0.1 & - & 0.1 \\
\hline Other Sources & 0.1 & 0.1 & - & - & - & - & 1.0 \\
\hline
\end{tabular}

'IPPC - Industrial activities as defined by the Integrated Pollution Prevention and Control Directive [12]

\section{Significant diffuse sources of pollution}

The way of using the land within the hydrographic space afferent to the Jiu Waters Administration is influenced by the physical-geographical conditions, as well as by the anthropic factors (figure 5) and, in turn, it influences the types and quantities of diffuse pollutants that reach the Jiu River waters.

Predominant in Jiu H.B. are arable lands (48.96\%), the forests being representative for $28.74 \%$ of the surface of the river basin [8]. Agricultural lands are predominant in the river basins of the most important direct tributaries $(54.12 \%)$. Perennial crops have a relatively uniform development, occupying $5.16 \%$. The other areas occupy much smaller areas. Thus the water tables occupy only $1.0 \%[7]$.

The main categories of sources of diffuse pollution are represented by [2]: 
1. Human agglomerations/localities that do not have wastewater collection systems or adequate systems for collecting and removing sludge from sewage treatment plants as well as localities with non-compliant household waste dumps.

2. Agriculture - agrozootechnical farms that do not have adequate manure storage/utilization systems, communes identified as vulnerable or potentially vulnerable to pollution by nitrates from agricultural sources, pesticide units that do not comply with the legislation in force, other units/agricultural activities that can lead to significant diffuse emissions.

The specific quantities of chemical fertilizers (expressed in active substance) used in 2016 were about $10 \%$ higher than the situation in 2012 , when at the level of Jiu hydrographic basin there were used average quantities of approx. $6.910 \mathrm{~kg} \mathrm{~N} / \mathrm{ha}$ of agricultural land, respectively $1.410 \mathrm{~kg} \mathrm{P} / \mathrm{ha}$ of agricultural land. In contrast, in 2016, compared with 2012, the specific quantities of natural fertilizers used decreased by approx. $10 \%[7]$.

3. Industry - warehouses of raw materials, finished products, auxiliary products, non-compliant waste storage, units producing diffuse accidental pollution, abandoned industrial sites.

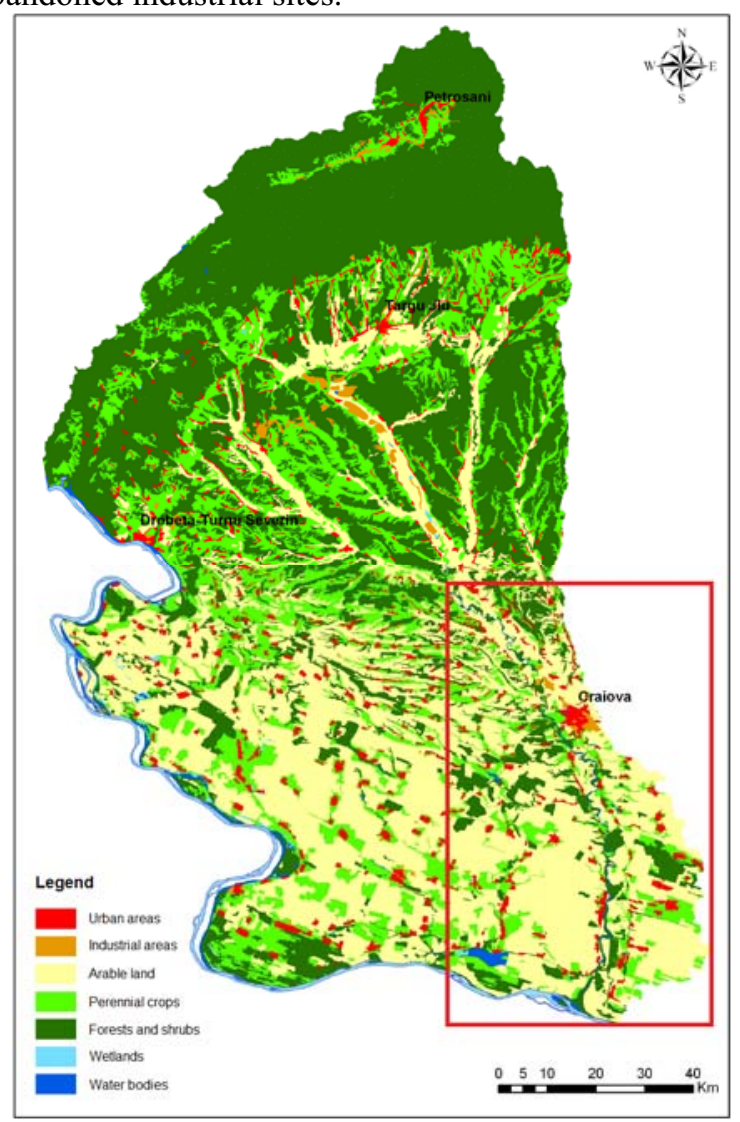

Fig. 5. Diffuse sources of pollution depending on the type of land use [7] (modified).

\subsection{Establishing the control and sampling sections}

Water samples were collected between January and December 2019, according to SR ISO 5667-6/2014 Water quality. Sampling Part 6: Guide for sampling of rivers and streams [13] (figure 6).



Fig. 6. Location of the sampling sections [15] (modified).

Establishing sampling locations has been done to allow for a comparative analysis. Sampling points can be located using fixed landmarks or GPS. Sampling points were clearly marked to avoid any confusion [2].

In establishing the sampling points the legal methodology was considered [14], as well as the location of the most important points in which untreated waste waters are discharged into the Jiu River on the territory of Dolj County.

For the collected of samples to be analyzed, in order to determine the quality of Jiu River in Dolj County, three control sections were established together with the Romanian Waters Administration (figure 6):

P1 - in Răcari de Jos village - downstream of Filiaşi, at the entrance to Dolj County;

P2 - in Podari village - downstream of Craiova City;

P3 - in Gângiova village - approx. $15 \mathrm{~km}$ upstream of the confluence with the Danube.

The collected water samples were transported to the authorized laboratory of the Romanian Water Administration - Craiova where the analyses were carried out according to the norms in force, the results of which are presented in the following paragraph.

\subsection{Quality classes of surface waters}

The surface water classification is based on the results of water quality monitoring and provides for a surface water classification a system divided in five quality classes defined by Order 161/2006 [16]:

Class I (very good) - surface waters where there are no (or very low) alterations in the physical-chemical and biological quality values. Concentrations of synthetic pollutants do not affect the functioning of aquatic ecosystems and do not harm human health. Surface waters corresponding to Class I can be designed for all types of use. Graphic representation uses blue color [16]. 
Class II (good) - surface waters that have been affected to some extent by human activity, but nevertheless ensure all uses in an appropriate manner. The functioning of aquatic ecosystems is not affected. Simple methods of treatment are sufficient to prepare drinking water. Graphic representation uses green color [16].

Class III (polluted) - surface waters whose high quality physical-chemical and biological values deviate moderately from the natural water quality background due to human activities. There are moderate signs of disturbance of the functioning of the ecosystem. The necessary conditions for the Salmonidae family can no longer be ensured. Simple treatment is not sufficient for the use of drinking water for normal treatment methods. Graphical representation uses yellow color [16].

Class IV (polluted) - surface waters that show evidence of major alterations in physical-chemical and biological quality values from the natural water quality background due to human activities. The conditions for the Cyprinidae family can no longer be assured and do not meet the requirements for drinking water without applying advanced treatment methods. Graphic representation uses orange color [16].

Class V (very polluted) - surface waters that show evidence of major alterations in physical-chemical and biological values from the natural water quality fund due to human activities. Biological components, especially fish, are damaged and water can not be used for drinking purposes. Graphic representation uses red color [16].

From the ecological point of view, the five qualities are the following:

- Class I quality - very good ecological status;

- Class II quality - good ecological status;

- Class III quality - moderate ecological status;

- Class IV quality - poor ecological status;

- Class V - very poor ecological status.

Table 4 presents the maximum admitted concentrations (M.A.C.) of pollutants and the quality class in which surface waters fall into according to these concentrations [16].

Table 4. Quality classes according to Order 161/2006 (extract).

\begin{tabular}{|c|c|c|c|c|c|c|c|c|}
\hline \multirow[t]{2}{*}{ No. } & \multirow[t]{2}{*}{ Group } & \multirow[t]{2}{*}{ Parameter } & \multirow[t]{2}{*}{ MU } & \multicolumn{5}{|c|}{\begin{tabular}{|c|} 
M.A.C. \\
Class of quality cf. Ord. 161/2006
\end{tabular}} \\
\hline & & & & I & II & III & IV & $\mathbf{V}$ \\
\hline 1 & \multirow{3}{*}{ Phisical indicators } & Temperature & ${ }^{\circ} \mathrm{C}$ & ns & ns & ns & ns & ns \\
\hline 2 & & $\overline{\mathrm{pH}}$ & $\mathrm{pH}$ unit & \multicolumn{5}{|c|}{$6.5-8.5$} \\
\hline 3 & & Suspensions & $\mathrm{mg} / \mathrm{l}$ & ns & ns & ns & ns & ns \\
\hline 4 & \multirow{3}{*}{ Oxygen regime } & Dissolved oxygen & $\mathrm{mgO}_{2} / 1$ & 7 & 6 & 5 & 4 & $<4$ \\
\hline 5 & & $\mathrm{CBO}_{5}$ & $\mathrm{mgO}_{2} / 1$ & 3 & 5 & 10 & 25 & $>25$ \\
\hline 6 & & $\mathrm{CCO}-\mathrm{Cr}$ & $\mathrm{mgO}_{2} / 1$ & 10 & 25 & 50 & 125 & $>125$ \\
\hline 7 & \multirow{6}{*}{ Nutrients } & $\mathrm{NH}_{4}^{-}$ & $\mathrm{mg} / \mathrm{l}$ & $<0.2$ & 0.2 & 0.3 & 0.6 & $>1.5$ \\
\hline 8 & & $\mathrm{NO}_{2}^{-}$ & $\mathrm{mg} / \mathrm{l}$ & 0.01 & 0.06 & 0.12 & 0.3 & $>0.3$ \\
\hline 9 & & $\mathrm{NO}_{3}^{-}$ & $\mathrm{mg} / \mathrm{l}$ & 1 & 3 & 6 & 15 & $>15$ \\
\hline 10 & & $\mathrm{~N}$ total & $\mathrm{mg} / \mathrm{l}$ & 1.5 & 4 & 8 & 20 & $>20$ \\
\hline 11 & & $\mathrm{PO}_{4}^{-3}$ & $\mathrm{mg} / \mathrm{l}$ & 0.05 & 0.1 & 0.2 & 0.5 & $>0.5$ \\
\hline 12 & & P total & $\mathrm{mg} / \mathrm{l}$ & 0.1 & 0.2 & 0.4 & 1 & $>1$ \\
\hline \begin{tabular}{|l|}
13 \\
\end{tabular} & \multirow{4}{*}{ General ions. salinity } & Filtrate residue at $105^{\circ} \mathrm{C}$ & $\mathrm{mg} / \mathrm{l}$ & background & 500 & 1000 & 1300 & $>1300$ \\
\hline \begin{tabular}{|l|}
14 \\
\end{tabular} & & $\mathrm{Ca}^{+2}$ & $\mathrm{mg} / \mathrm{l}$ & 75 & 150 & 200 & 300 & $>300$ \\
\hline 15 & & $\mathrm{Cl}^{-}$(chlorine) & $\mathrm{mg} / \mathrm{l}$ & background & 100 & 250 & 300 & $>300$ \\
\hline 16 & & $\mathrm{SO}_{4}^{-2}$ & $\mathrm{mg} / 1$ & 80 & 150 & 250 & 300 & $>300$ \\
\hline \begin{tabular}{|l|}
17 \\
\end{tabular} & \multirow{3}{*}{ Organic substances } & Phenols & $\mu \mathrm{g} / 1$ & background & 1 & 20 & 50 & 250 \\
\hline 18 & & Detergents & $\mu \mathrm{g} / 1$ & background & 500 & 750 & 1000 & $>1000$ \\
\hline \begin{tabular}{|l|}
19 \\
\end{tabular} & & \begin{tabular}{|l} 
Fecal Coliforms \\
\end{tabular} & col./100 ml & 100 & \begin{tabular}{|c|}
2000 \\
2000
\end{tabular} & \begin{tabular}{|c|}
$\mathrm{ns}$ \\
\end{tabular} & \begin{tabular}{|c|}
$\mathrm{ns}$ \\
\end{tabular} & $\mathrm{ns}$ \\
\hline
\end{tabular}

MU - measuring unit; ns - not standardized.

\section{Results and discussions}

\subsection{Water quality of Jiu River in 2019}

In order to assess the Jiu River water quality in Dolj County, we have performed a comparative analysis of the characteristic quality parameters for the three sampling points (P1, P2 and P3) presented in tables 5 - 7 .

The analyses regarding the water quality of the Jiu River were performed by the qualified personnel of Jiu Craiova Water Basin Administration.

In a previous study, conducted in May 2017 [2], it was found that the quality of Jiu River in Dolj County is medium (moderate ecological status).
Analyzing the data presented in tables $5-7$, several conclusions can be drawn:

- The dissolved oxygen shows values which are consistent to the first class of quality except for two determinations made in P2 and P3 in July. Thus, the degree of saturation in $\mathrm{P} 1$ is of $82.45 \%$, which also qualifies Jiu River in the first quality class. This parameter is affected, by a decrease in value, so at point P3 the value reaches only $75.96 \%$. This evolution is due to the organic pollutant load added between the sampling sections;

- $\mathrm{CBO}_{5}$ is a parameter in correlation with dissolved oxygen (its evolution is in the opposite direction). At sampling section P1 we have low average oxygen biochemical consumption $(5.73 \mathrm{mg} / \mathrm{l})$, which increases in $\mathrm{P} 2$ to $6.14 \mathrm{mg} / \mathrm{l}$ and in $\mathrm{P} 3$ to $6.34 \mathrm{mg} / \mathrm{l}$. The determined values place Jiu River in the third class of quality, a moderate ecological state; 
Table 5. Central table on Jiu River water quality at P1 (Răcari) monitoring point (2019).

\begin{tabular}{|c|c|c|c|c|c|c|c|c|c|c|c|c|c|c|}
\hline \multirow{3}{*}{ No. } & \multirow{3}{*}{ Parameter } & \multirow{3}{*}{ MU } & \multicolumn{12}{|c|}{ P1 - RĂCARI } \\
\hline & & & \multicolumn{12}{|c|}{ Month } \\
\hline & & & I & II & III & IV & $\mathbf{V}$ & VI & VII & VIII & IX & $\mathbf{X}$ & XI & XII \\
\hline 1 & Temperature water/air & ${ }^{\circ} \mathrm{C}$ & $4 / 6$ & $3 / 5$ & $7 / 14$ & $11 / 15$ & $18 / 19$ & $19 / 24$ & $20 / 26$ & $20 / 26$ & $17 / 19$ & $14 / 16$ & $8 / 10$ & $4 / 5$ \\
\hline 2 & $\mathrm{pH}\left(22.0^{\circ} \mathrm{C}\right)$ & $\mathrm{UpH}$ & 7.96 & 7.76 & 7.67 & 7.76 & 7.96 & 7.98 & 8.06 & 7.68 & 7.87 & 7.88 & 7.78 & 7.77 \\
\hline 3 & Total suspensior & $\mathrm{mg} / \mathrm{l}$ & 6 & 3.4 & 8.5 & 4.4 & 6 & 3.9 & 4 & 4.9 & 8 & 5.6 & 4 & 3.9 \\
\hline 4 & Conductivity & $\mu \mathrm{S} / \mathrm{cm}$ & 356 & 334 & 387 & 324 & 356 & 298 & 296 & 287 & 301 & 312 & 293 & 267 \\
\hline 5 & \begin{tabular}{|l} 
Filtrated residue at \\
$105^{\circ} \mathrm{C}$
\end{tabular} & $\mathrm{mg} / \mathrm{l}$ & 214 & 212 & 245 & 167 & 214 & 155 & 277 & 176 & 299 & 187 & 224 & 143 \\
\hline 6 & Dissolved oxygen & $\mathrm{mg} / \mathrm{l}$ & 8.6 & 7.6 & 7.6 & 8.6 & 8.6 & 7.7 & 8.6 & 8.7 & 8.6 & 7.7 & 8.6 & 8.9 \\
\hline 7 & Satur & $\%$ & 82.45 & 78.45 & \begin{tabular}{|l|}
80.45 \\
\end{tabular} & 85.35 & 82.45 & 78.45 & 79.41 & 80.45 & 86.56 & 78.44 & 67.41 & 85.34 \\
\hline 8 & $\mathrm{CBO}_{5}$ & $\mathrm{mg} / \mathrm{l}$ & 5.5 & 5.2 & 6.5 & 4.2 & 5.5 & 5.4 & 7.5 & 6.4 & 5.5 & 6.2 & 5.5 & 5.4 \\
\hline 9 & $\mathrm{CCO}-$ & $\mathrm{mg} / \mathrm{l}$ & 19.21 & 18.31 & 20.23 & 18.22 & 19.21 & 19.54 & 20.15 & 19.89 & 23.25 & 19.23 & 20.46 & 18.81 \\
\hline 10 & Alka & $\mathrm{mmol} / \mathrm{l}$ & 2.369 & 2.249 & 2.322 & 2.209 & 2.369 & 2.104 & 2.143 & 2.213 & 2.082 & 2.201 & 2.087 & 2.201 \\
\hline 11 & Bica & $\mathrm{mg} / \mathrm{l}$ & 144.51 & 134.31 & 146.76 & 133.34 & 144.51 & 144.32 & 139.51 & 156.56 & 150.67 & 145.57 & 149.52 & 156.34 \\
\hline \begin{tabular}{|l|}
12 \\
\end{tabular} & Chl & $\mathrm{g} / \mathrm{l}$ & .521 & 14.641 & 16.523 & 15.612 & 15.521 & 15.224 & 17.343 & 17.284 & 16.357 & 18.222 & 19.356 & 19.244 \\
\hline 13 & S & $\mathrm{g} / \mathrm{l}$ & 3.228 & 70.228 & 69.224 & 65.218 & 73.228 & 69.763 & 72.234 & 68.763 & 73.466 & 71.398 & 71.221 & 69.162 \\
\hline 14 & $\mathrm{~N}-\mathrm{NH}_{4}$ & $\mathrm{mgN} / 1$ & 0.0250 & 0.0245 & 0.0258 & 0.0199 & 0.0250 & 0.0255 & 0.0265 & 0.0245 & 0.0235 & 0.0256 & 0.0235 & 0.0235 \\
\hline 15 & Nitrates - N-NO & $\mathrm{mgN} / 1$ & 0.7525 & 0.6578 & 0.8534 & 0.5571 & 0.7525 & 0.5589 & 0.7432 & 0.5454 & 0.6739 & 0.4954 & 0.5632 & 0.4954 \\
\hline 16 & $\mathrm{~N}-\mathrm{NO}_{2}$ & $\mathrm{mgN} / 1$ & 0.0088 & 0.0072 & 0.0078 & 0.0062 & 0.0088 & 0.0098 & 0.0089 & 0.0089 & 0.0079 & 0.0090 & 0.0071 & 0.0067 \\
\hline 17 & Total & $\mathrm{mg} / \mathrm{l}$ & 0.9578 & 0.9235 & 1.0078 & 0.9125 & 0.9578 & 0.8735 & 1.0078 & 0.8567 & 1.0009 & 0.8589 & 1.0009 & 0.7367 \\
\hline 18 & $-\mathrm{P}-\mathrm{PO}_{4}$ & $\mathrm{mgP} / 1$ & 0.0454 & 0.0514 & 0.0456 & 0.0494 & 0.0454 & 0.0598 & 0.0453 & 0.0498 & 0.0465 & 0.0478 & 0.0451 & 0.039 \\
\hline 19 & $\begin{array}{l}\text { Total phosphorus - } \\
\text { PT }\end{array}$ & $\mathrm{g} / \mathrm{l}$ & 0.0610 & 0.0614 & 0.0614 & 0.0611 & 0.0610 & 0.0615 & 0.0615 & 0.0598 & 0.0622 & $\mid 0.0566$ & 0.0605 & 0.05 \\
\hline 20 & Calcium & $\mathrm{mg} / \mathrm{l}$ & 55.132 & 55.342 & 52.145 & 55.278 & 55.132 & 52.321 & 56.032 & 55.367 & 54.109 & \begin{tabular}{|l|}
52.289 \\
\end{tabular} & 55.125 & 58.564 \\
\hline 21 & Dete & $\mathrm{mg} / \mathrm{l}$ & 0.105 & 0.123 & \begin{tabular}{|l|}
0.124 \\
\end{tabular} & 0.117 & \begin{tabular}{|l|}
0.105 \\
\end{tabular} & 0.144 & 0.144 & 0.167 & 0.150 & \begin{tabular}{|l|}
0.130 \\
\end{tabular} & 0.151 & 0.122 \\
\hline \begin{tabular}{|l|}
22 \\
\end{tabular} & Phenols & $\mathrm{mg} / \mathrm{l}$ & $<0.004$ & $<0.004$ & $<0.004$ & $<0.004$ & $<0.004$ & $<0.004$ & $<0.004$ & $<0.004$ & $<0.004$ & $<0.004$ & $<0.004$ & $<0.004$ \\
\hline 23 & Hardness & $\begin{array}{l}\mathrm{mg} / 1 \\
\mathrm{CaCO}_{3}\end{array}$ & 263.63 & 264.61 & 243.63 & 266.65 & 263.63 & 245.62 & 277.61 & 251.87 & 256.64 & 249.45 & 281.63 & 254.3 \\
\hline
\end{tabular}

Table 6. Central table on Jiu River water quality at P2 (Podari) monitoring point (2019).

\begin{tabular}{|c|c|c|c|c|c|c|c|c|c|c|c|c|c|c|}
\hline \multirow{3}{*}{ No. } & \multirow{3}{*}{ Parameter } & \multirow{3}{*}{ MU } & \multicolumn{12}{|c|}{ P2 - PODARI } \\
\hline & & & \multicolumn{12}{|c|}{ Month } \\
\hline & & & I & II & III & IV & $\mathbf{V}$ & VI & VII & VIII & IX & $\mathbf{X}$ & $\mathbf{X I}$ & XII \\
\hline 1 & $\begin{array}{l}\text { Temperature } \\
\text { water/air }\end{array}$ & ${ }^{\circ} \mathrm{C}$ & $4 / 6$ & $3 / 5$ & $7 / 15$ & $11 / 16$ & $18 / 20$ & $20 / 25$ & $20 / 27$ & $20 / 26$ & $17 / 20$ & $14 / 16$ & $8 / 10$ & $5 / 6$ \\
\hline 2 & $\mathrm{pH}\left(22.0^{\circ} \mathrm{C}\right)$ & $\mathrm{UpH}$ & 8.03 & 7.83 & 7.73 & 7.87 & 8.03 & 8.03 & 8.01 & 7.86 & 7.86 & 7.89 & 7.72 & 7.86 \\
\hline 3 & Total suspensions & $\mathrm{mg} / \mathrm{l}$ & 4.2 & 4.3 & 9.2 & 4.9 & 4.2 & 4.2 & 3.8 & 4.2 & 7.8 & 7.6 & 3.9 & 4.1 \\
\hline 4 & Conductivity & $\mu \mathrm{S} / \mathrm{cm}$ & 457 & 445 & 477 & 395 & 457 & 378 & 388 & 298 & 346 & 356 & 356 & 268 \\
\hline 5 & $\begin{array}{l}\text { Filtrated residue at } \\
105^{\circ} \mathrm{C}\end{array}$ & $\mathrm{mg} / \mathrm{l}$ & 274 & 254 & 298 & 193 & 274 & 209 & 293 & 211 & 331 & 213 & 267 & 178 \\
\hline 6 & Dissolved oxygen & $\mathrm{mg} / \mathrm{l}$ & 9.0 & 8.0 & 8.0 & 8.0 & 9.0 & 8.1 & 6.4 & 7.9 & 8.4 & 8.9 & 9.1 & 9.5 \\
\hline 7 & Saturati & $\%$ & 83.41 & 82.41 & 83.41 & 80.38 & 83.41 & 83.42 & 78.43 & 83.55 & 84.76 & 87.53 & 78.43 & 88.57 \\
\hline 8 & $\mathrm{CBO}_{5}$ & $\mathrm{mg} / \mathrm{l}$ & 5.6 & 5.6 & 7.6 & 5.5 & 5.6 & 5.7 & 7.6 & 6.7 & 5.7 & 6.6 & 5.6 & 5.9 \\
\hline 9 & $\mathrm{CCO}-\mathrm{Cr}$ & $\mathrm{mg} / \mathrm{l}$ & 23.49 & 22.34 & 27.45 & 23.31 & 23.49 & 22.78 & 23.41 & 21.98 & 23.67 & 22.56 & 23.44 & 22.34 \\
\hline 10 & Alkalin & $\mathrm{mmol} / \mathrm{l}$ & 2.848 & 2.788 & 2.746 & 2.691 & 2.848 & 2.548 & 2.762 & \begin{tabular}{|l|}
2.468 \\
\end{tabular} & 2.456 & 2.208 & 2.482 & 2.412 \\
\hline 11 & Bicar & $\mathrm{mg} / \mathrm{l}$ & 173.73 & 165.76 & 177.73 & 155.71 & 173.73 & 165.76 & 156.31 & 164.74 & 157.463 & 161.71 & 154.67 & 162.72 \\
\hline 12 & Chlorin & $\mathrm{mg} / \mathrm{l}$ & 23.030 & 21.134 & 22.033 & 21.245 & 23.030 & 20.143 & \begin{tabular}{|l|}
21.132 \\
\end{tabular} & 21.003 & 20.367 & 20.023 & 20.765 & 21.155 \\
\hline 13 & Sulphate & $\mathrm{mg} / \mathrm{l}$ & 78.428 & 68.658 & 74.435 & 68.158 & 78.428 & 68.674 & \begin{tabular}{|l|}
75.433 \\
\end{tabular} & 69.677 & 75.187 & 70.387 & 75.167 & 69.689 \\
\hline 14 & Ammonium - N- $\mathrm{NH}_{4}$ & $\mathrm{mgN} / 1$ & 0.0605 & 0.0565 & 0.0703 & 0.0369 & 0.0605 & 0.0462 & 0.0613 & 0.0362 & 0.0489 & 0.0312 & 0.0432 & 0.0262 \\
\hline 15 & Nitrates - N-NO 3 & $\mathrm{mgN} / 1$ & 1.1200 & 1.0100 & 1.2346 & 1.0092 & 1.1200 & 0.8965 & 1.1376 & 0.8778 & 1.0897 & 0.7893 & 0.9376 & 0.7989 \\
\hline 16 & Nitrites - N-NO & $\mathrm{mgN} / 1$ & 0.0154 & 0.0134 & 0.0145 & 0.0109 & 0.0154 & 0.0146 & 0.0157 & 0.0133 & 0.0187 & 0.0118 & 0.0123 & 0.0121 \\
\hline 17 & Total nitrate $-\mathrm{N}$ & $\mathrm{mg} / \mathrm{l}$ & 1.4530 & 1.4240 & 1.4678 & 1.3221 & 1.4530 & 1.0940 & 1.5033 & 1.0678 & 1.3890 & 1.0871 & 1.4067 & 1.0008 \\
\hline 18 & O-phosphate $-\mathrm{P}-\mathrm{PO}_{4}$ & $\mathrm{mgP} / \mathrm{l}$ & 0.0804 & 0.0804 & 0.0224 & 0.0794 & 0.0204 & 0.0946 & 0.0215 & 0.0879 & 0.0783 & 0.0799 & 0.0234 & 0.0768 \\
\hline 19 & $\begin{array}{l}\text { Total phosphorus - } \\
\text { PT }\end{array}$ & $\mathrm{mg} / \mathrm{l}$ & 0.0268 & 0.0938 & 0.0298 & 0.1229 & 0.0268 & 0.1238 & 0.0289 & 0.1157 & 0.0879 & 0.1076 & 0.0276 & 0.1001 \\
\hline 20 & Calcium & $\mathrm{mg} / \mathrm{l}$ & 75.878 & 76.658 & 73.357 & 69.644 & 75.878 & 66.244 & 74.575 & 63.233 & 64.480 & 61.209 & 73.445 & 65.453 \\
\hline 21 & Detergents ANA & $\mathrm{mg} / \mathrm{l}$ & 0.150 & 0.147 & 0.146 & 0.143 & 0.150 & 0.179 & \begin{tabular}{|l|}
0.153 \\
\end{tabular} & \begin{tabular}{|l|}
0.188 \\
\end{tabular} & 0.153 & 0.158 & 0.158 & 0.167 \\
\hline 22 & Phenols & $\mathrm{mg} / \mathrm{l}$ & $<0.004$ & $<0.004$ & $<0.004$ & $<0.004$ & $<0.004$ & $<0.004$ & $<0.004$ & $<0.004$ & $<0.004$ & $<0.004$ & $<0.004$ & $<0.004$ \\
\hline 23 & Hard & $\begin{array}{l}\mathrm{mg} / \mathrm{l} \\
\mathrm{CaCO}_{3}\end{array}$ & 282.51 & 284.46 & 265.31 & 280.51 & 282.51 & 276.59 & 275.53 & 278.55 & 276.98 & 255.25 & 271.45 & 278. \\
\hline
\end{tabular}


Table 7. Central table on Jiu River water quality at P3 (Gângiova) monitoring point (2019).

\begin{tabular}{|c|c|c|c|c|c|c|c|c|c|c|c|c|c|c|}
\hline \multirow{3}{*}{ No. } & \multirow{3}{*}{ Parameter } & \multirow{3}{*}{ MU } & \multicolumn{12}{|c|}{ P3 - GÂNGIOVA } \\
\hline & & & \multicolumn{12}{|c|}{ Month } \\
\hline & & & I & II & III & IV & $\mathbf{V}$ & VI & VII & VIII & IX & $\mathbf{X}$ & XI & XII \\
\hline 1 & Temperature & ${ }^{\circ} \mathrm{C}$ & $4 / 7$ & $4 / 5$ & $8 / 15$ & $11 / 16$ & $19 / 20$ & $21 / 25$ & $21 / 27$ & $20 / 26$ & $17 / 20$ & $14 / 17$ & $8 / 10$ & $6 / 6$ \\
\hline 2 & $\mathrm{pH}\left(22.0^{\circ} \mathrm{C}\right)$ & $\mathrm{UpH}$ & 7.62 & 7.84 & 7.82 & 7.94 & 7.62 & 7.94 & 7.99 & 7.91 & 7.91 & 7.93 & 7.81 & 7.95 \\
\hline 3 & Total suspensions & $\mathrm{mg} / \mathrm{l}$ & 8 & 7.5 & 9.8 & 6.5 & 8 & 6.5 & 4.2 & 6.5 & 8.2 & 8.5 & 4.1 & 6.3 \\
\hline 4 & Conductivity & $\mu \mathrm{S} / \mathrm{cm}$ & 489 & 487 & 499 & 436 & 489 & 417 & 492 & 349 & 387 & 388 & 397 & 290 \\
\hline 5 & \begin{tabular}{|l} 
Filtrated residue at \\
$105^{\circ} \mathrm{C}$
\end{tabular} & $\mathrm{mg} / \mathrm{l}$ & 293 & 287 & 302 & 237 & 293 & 267 & 313 & 258 & 334 & 243 & 287 & 208 \\
\hline 6 & Dissolved oxygen & $\mathrm{ng} / \mathrm{l}$ & 8.5 & 8.1 & 7.5 & 8.4 & 8.5 & 8.1 & 6.1 & 7.2 & 8.9 & 8.0 & 7.9 & 8.7 \\
\hline 7 & Satu & $\%$ & 80.96 & 82.96 & 80.16 & 83.96 & 80.96 & 82.96 & 81.92 & 82.65 & 88.32 & 82.45 & 81.92 & 82.65 \\
\hline 8 & $\mathrm{CBO}_{5}$ & $\mathrm{mg} / \mathrm{l}$ & 5.7 & 5.7 & 7.7 & 5.7 & 5.7 & 5.9 & 7.7 & 6.9 & 6.1 & 7.2 & 5.9 & 5.9 \\
\hline 9 & $\mathrm{CCO}-$ & $\mathrm{mg} / \mathrm{l}$ & 22.41 & 22.56 & 27.67 & 23.59 & 22.41 & 23.06 & 23.51 & 23.15 & 24.19 & 23.76 & 23.98 & 23.56 \\
\hline 10 & Alka & $\mathrm{nmol} / 1$ & 3.210 & 3.010 & 3.119 & 3.014 & 3.210 & 2.903 & 3.101 & 2.877 & 2.795 & 2.571 & 2.908 & 2.578 \\
\hline 11 & Bice & $\mathrm{mg} / \mathrm{l}$ & 195.81 & 194.31 & 189.89 & 184.48 & 195.81 & 187.86 & 194.65 & 189.22 & 189.16 & 182.16 & 184.59 & 187.65 \\
\hline \begin{tabular}{|l|}
12 \\
\end{tabular} & C & $\mathrm{g} / \mathrm{l}$ & .989 & 25.567 & 24.186 & 25.217 & 26.989 & 25.282 & 24.934 & 24.282 & 23.798 & 23.109 & 23.905 & 23.233 \\
\hline 13 & Sulp & $\mathrm{ng} / \mathrm{l}$ & 78.724 & 76.454 & 78.356 & 69.434 & \begin{tabular}{|l|}
78.724 \\
\end{tabular} & 73.503 & 78.083 & 73.233 & 76.389 & 73.193 & 78.003 & 72.543 \\
\hline 14 & $\mathrm{~N}-\mathrm{NH}_{4}$ & $\mathrm{mgN} / 1$ & 0.5964 & 0.4964 & 0.5863 & 0.3924 & 0.5964 & 0.3990 & 0.4984 & 0.4093 & 0.3984 & 0.3907 & 0.3875 & 0.3488 \\
\hline 15 & Nitrates - N-NO & $\mathrm{mgN} / 1$ & 1.1650 & 1.1230 & 1.3460 & 1.1145 & 1.1650 & 1.1009 & 1.1852 & 1.1106 & 1.1289 & 1.1209 & 1.1156 & 1.1078 \\
\hline 16 & $\mathrm{~N}-\mathrm{NO}_{2}$ & $\mathrm{mgN} / 1$ & 0.0325 & 0.0255 & 0.0305 & 0.0225 & 0.0325 & 0.0242 & 0.0334 & 0.0245 & 0.0278 & 0.0221 & 0.0278 & 0.0215 \\
\hline \begin{tabular}{|l|}
17 \\
\end{tabular} & Total & $\mathrm{mg} / \mathrm{l}$ & 2.3180 & 2.2140 & 2.3421 & 2.2067 & 2.3180 & 1.2271 & 2.3420 & 1.2167 & 1.9087 & 1.2188 & 2.0098 & 1.1156 \\
\hline \begin{tabular}{|l|}
18 \\
\end{tabular} & $\mathrm{P}-\mathrm{PO}_{4}$ & $\mathrm{ngP} / 1$ & 0.1895 & 0.1675 & 0.1769 & 0.1573 & 0.1895 & 0.1572 & 0.1785 & 0.1438 & 0.1309 & 0.1391 & 0.1567 & 0.1249 \\
\hline 19 & $\begin{array}{l}\text { Total phosphorus - } \\
\text { PT }\end{array}$ & $\mathrm{g} / \mathrm{l}$ & 0.2574 & 0.2273 & 0.2464 & 0.2189 & 0.2574 & 0.2273 & 0.2400 & 0.2154 & 0.198 & 0.1997 & 0.2162 & 0.198 \\
\hline 20 & Calcium & $\mathrm{g} / 1$ & 62.962 & 66.921 & 69.462 & 67.965 & 62.962 & 66.956 & 62.764 & 65.678 & 65.387 & 63.571 & 68.712 & 66.429 \\
\hline 21 & Dete & $\mathrm{mg} / \mathrm{l}$ & 0.132 & 0.149 & \begin{tabular}{|l|}
0.156 \\
\end{tabular} & 0.155 & \begin{tabular}{|l|}
0.132 \\
\end{tabular} & 0.209 & 0.161 & 0.212 & \begin{tabular}{|l|}
0.176 \\
\end{tabular} & 0.199 & 0.176 & 0.189 \\
\hline \begin{tabular}{|l|}
22 \\
\end{tabular} & Phenols & $\mathrm{mg} / \mathrm{l}$ & $<0.004$ & $<0.004$ & $<0.004$ & $<0.004$ & $<0.004$ & $<0.004$ & $<0.004$ & $<0.004$ & $<0.004$ & $<0.004$ & $<0.004$ & $<0.004$ \\
\hline 23 & Hardness & $\begin{array}{l}\mathrm{mg} / 1 \\
\mathrm{CaCO}_{3}\end{array}$ & 266.36 & 256.39 & 256.37 & 266.31 & 266.36 & 266.31 & 267.65 & 267.18 & 268.49 & 261.68 & 288.34 & 279. \\
\hline
\end{tabular}

- The chemical oxygen consumption puts Jiu River in the second category of quality, except for March when, in P2 and P3, it falls into the third category;

- The $\mathrm{pH}$ value falls within the range of variations characteristic to natural water courses, with a slightly basic character that can be explained by the intake of waters rich in carbonates;

- The temperature of Jiu River varies between 3 and $21^{\circ} \mathrm{C}$ (lowest in February at P1, Răcari and P2, Podari, respectively, highest in June and July at P3, Gângiova). This variation is normal, and it is attributed to the influence of air temperature as can be seen from the tables. We do not consider that the discharge of waters with slightly higher temperature from the two power plants (Işalniţa and Craiova II Electric Power Plants) have a significant influence on the overall temperature of the river. We can also observe a small increase in temperature for each individual month from P1 towards P3. However this increase is also attributed to the increase of air temperature in between sampling;

- The nitrates concentration suffers a negative change (the average concentration rising from $0.63 \mathrm{mg} / 1$ in $\mathrm{P} 1$ to $1.14 \mathrm{mg} / \mathrm{l}$ in P3), suggesting that sewage discharges occur between the analysis sections (or wastewaters from zootechnical farms);

- The nitrites concentration suffers a negative change. The average concentration places Jiu River in the first quality class in P1 and in the second class in P2 and P3 (it increases from $0.008 \mathrm{mg} / 1$ in $\mathrm{P} 1$, to $0.014 \mathrm{mg} / 1$, reaching $0.027 \mathrm{mg} / \mathrm{l}$ in P3). This evolution confirms that discharges of sewage and zootechnical wastewaters occur between the sampling sections;

- The evolution of the total nitrite concentration follows the same pattern as the concentrations of nitrates and nitrites (from an average of $0.92 \mathrm{mg} / \mathrm{l}$ in P1, corresponding to the first quality class, up to $1.87 \mathrm{mg} / \mathrm{l}$ in $\mathrm{P} 3$, corresponding to the second quality class);

- The average phosphate concentration increases between P1 (from $0.047 \mathrm{mg} / 1$ - first quality class) and the next two sampling sections (up to $0.062 \mathrm{mg} / \mathrm{l}$ in P2 and $0.159 \mathrm{mg} / \mathrm{l}$ in P3), corresponding to the second class of quality;

- The average total phosphorus content also increases from P1 towards P3. In the first two sampling sections the average concentrations (of $0.060 \mathrm{mg} / 1$ in P1 and 0.074 $\mathrm{mg} / \mathrm{l}$ in P2) places Jiu River in the first quality class, while for the third sampling section, with a average concentration of $0.225 \mathrm{mg} / \mathrm{l}$, Jiu River falls into the third quality class.

- Turbidity evolution is influenced in turn by domestic wastewater spillage and due to the high hydraulic stability of the suspended particles, favored by the predominantly laminar flow regime.

- The concentration of total dissolved salts (determined by the conductivity) is similar in evolution (increases in P3 compared to P1), appreciating that this is achieved mainly by the intake of wastewaters with higher content of salts.

- From the point of view of fecal coliforms, Jiu River falls into the second category of quality, having a good ecological status; 
- For the rest of the analyzed parameters Jiu River falls into the first quality class.

As a general conclusion, considering the water quality of Jiu River in the analyzed sections, in terms of the determined values of the selected parameters compared with those listed in Order 161/2006, and taking into account the recommendations from it, we can say that the wastewater generated by industrial, agricultural and household activities and which are discharged directly into it, have a negative influence. However, the quality of Jiu River does not suffer a significant worsening, falling into the third category in all three control sections.

\subsection{Control method}

Another way of assessing the quality of Jiu River water for the three control sections is based on the calculation of the Water Quality Index (WQI).

The WQI was conceptually defined in the early 1970's by the US National Sanitation Foundation (NSF) to compare water quality from different water sources and to monitor water quality variations over time. For this purpose, 142 experts carried out 25 different tests and selected 9 indicators, with the main objective of aggregating individual indicators (expressed in physical units) into a single water quality index (on a conventional scale 0 - 100) [17]. The steps to achieve the set goal were as follows:

- Translating each of the 9 indicators into a quality index;

- Performing a weighted average of the obtained values.

This method involves the interpolation of the result of the water quality parameters analysis with a series of predefined curves (shown in the literature) to obtain the value of $Q$ indicators, after which to the Qi values will be assigned a given weight $\mathrm{Wi}$, and the quality index is calculated by the formula WQI $=\Sigma$ QiWi $[18,19]$.

For each sample a table is produced with all the results for the water quality parameters, and then using the scale of quality (table 8) we determine the quality of the water according to the calculated score $[20,21]$.

Table 8. Quality scale for WQI [17] (modified).

\begin{tabular}{|c|c|c|c|}
\hline Points & Quality & Category & Correspondence with Ord. 161/2006 \\
\hline $91-100$ & excellent & A & I \\
\hline $71-90$ & good & B & II \\
\hline $51-70$ & medium & C & III \\
\hline $26-50$ & poor & D & IV \\
\hline $0-25$ & very poor & E & V \\
\hline
\end{tabular}

Table 9 presents the data which are at the base on the calculation of the water quality index for the three control sections considered on the Jiu River, and table 10 presents the values determined for $\mathrm{Q}$ in order to characterize its quality in Dolj County (for the three control sections). As can be seen, for the calculation of the water quality index additional analyzes were performed for the determination of fecal coliforms, turbidity and dissolved solids.

Table 9. Indicators required for WQI calculation (average values)

\begin{tabular}{|c|l|c|c|c|c|}
\hline \multirow{2}{*}{ No. } & \multirow{2}{*}{ Indicator } & \multirow{2}{*}{ UM } & \multicolumn{3}{c|}{ Sampling section } \\
\cline { 4 - 6 } & & & Răcari & Podari & Gângiova \\
\hline 1 & Dissolved oxygen & $\%$ & 82.45 & 82.41 & 75.96 \\
\hline 2 & Fecal coliforms & colonies/100ml & 180 & 268 & 280 \\
\hline 3 & CBO 5 & $\mathrm{mg} / 1$ & 5.73 & 6.14 & 6.34 \\
\hline 4 & $\mathrm{pH}$ & & 7.84 & 7.89 & 7.85 \\
\hline 5 & Nitrates & $\mathrm{mg} / 1$ & 0.63 & 1.00 & 1.14 \\
\hline 6 & Temperature & ${ }^{\circ} \mathrm{C}$ & 17 & 17 & 17 \\
\hline 7 & Total phosphates & $\mathrm{mg} / 1$ & 0.047 & 0.062 & 0.159 \\
\hline 8 & Turbidity & $\mathrm{NTU}$ & 28 & 58 & 61 \\
\hline 9 & TDS & $\mathrm{mg} / 1$ & 0.35 & 0.71 & 0.79 \\
\hline
\end{tabular}

Table 10. Calculated values for determination of WQI.

\begin{tabular}{|c|c|c|c|c|c|c|c|c|c|c|}
\hline \multirow{2}{*}{ No. } & \multirow{2}{*}{ Indicator } & \multicolumn{3}{|c|}{ P1 Răcari } & \multicolumn{3}{|c|}{ P2 Podari } & \multicolumn{3}{|c|}{ P3 Gângiova } \\
\hline & & \begin{tabular}{|l|} 
Value $\mathbf{O}_{i}$ \\
\end{tabular} & Proportion $\mathbf{W}_{\mathrm{i}}$ & Total & Value $\mathbf{O}_{\mathrm{i}}$ & Proportion $\mathbf{W}_{\mathrm{i}}$ & Total & \begin{tabular}{|l|} 
Value $\mathbf{O}_{i}$ \\
\end{tabular} & Proportion W & Total \\
\hline 1 & Dissolved oxygen & 90 & 0.17 & 15.3 & 90 & 0.17 & 15.3 & 80 & 0.17 & 13.6 \\
\hline 2 & Fecal coliforms & 50 & 0.11 & 5.5 & 42 & 0.11 & 4.62 & 41 & 0.11 & 4.51 \\
\hline 3 & $\mathrm{CBO}_{5}$ & 52 & 0.11 & 5.72 & 51 & 0.11 & 5.61 & 52 & 0.11 & 5.72 \\
\hline 4 & $\mathrm{pH}$ & 89 & 0.11 & 9.79 & 89 & 0.11 & 9.79 & 89 & 0.11 & 9.79 \\
\hline 5 & Nitrates & 97 & 0.1 & 9.7 & 95 & 0.1 & 9.5 & 90 & 0.1 & 9 \\
\hline 6 & Temperature & 25 & 0.1 & 2.5 & 25 & 0.1 & 2.5 & 25 & 0.1 & 2.5 \\
\hline 7 & Total phosphates & 99 & 0.1 & 9.9 & 98 & 0.1 & 9.8 & 95 & 0.1 & 9.5 \\
\hline 8 & Turbidity & 52 & 0.08 & 4.16 & 34 & 0.08 & 2.72 & 33 & 0.08 & 2.64 \\
\hline 9 & TDS & 80 & 0.07 & 5.6 & 80 & 0.07 & 5.6 & 80 & 0.07 & 5.6 \\
\hline 10 & TOTAL (WQI) & - & - & 68.17 & - & - & 65.44 & - & - & 62.86 \\
\hline
\end{tabular}


Using the three values calculated for the WQI, the chart in figure 7 was constructed, which allows us to observe how the Jiu River water quality evolves on the section investigated in Dolj County.

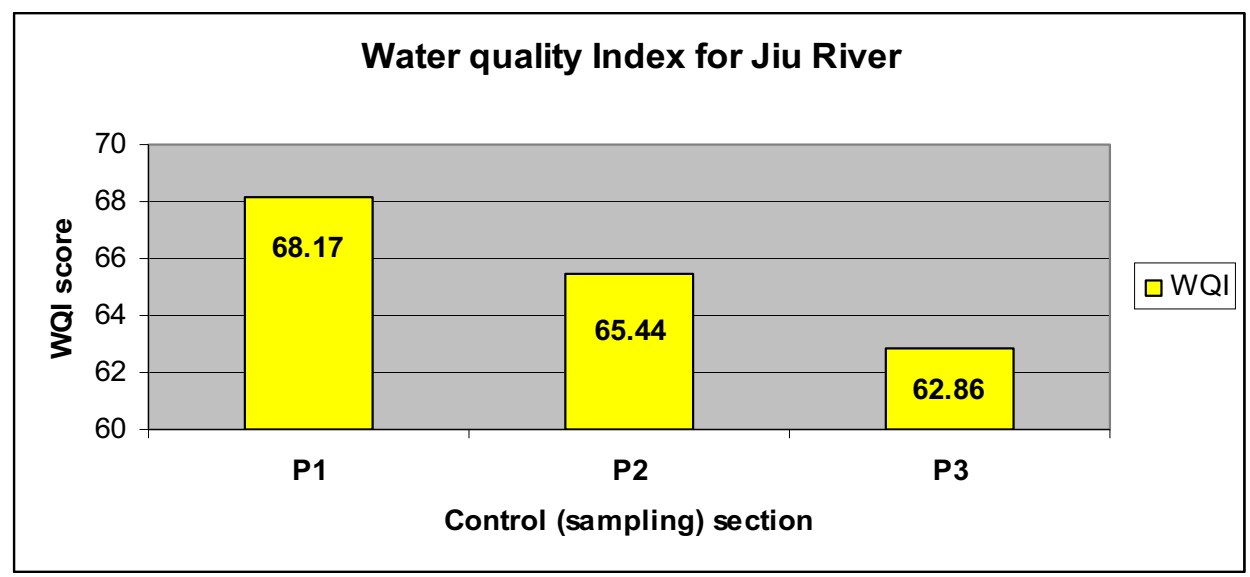

Fig. 7. Values of the Water Quality Index in the three control sections.

Although the value of the Water Quality Index falls slightly from P1 to P3, from the point of view of classification, the water of the Jiu River remains of medium quality (class C or III ${ }^{\text {rd }}$ of quality) according with the methodology.

\section{Conclusions}

In the context of sustainable development, the protection of surface water quality occupies a major place, considering that water, which has long been considered an inexhaustible and renewable resource, is becoming increasingly obvious as one of the limiting factors in the socio-economic development of the modern society. As a major environmental factor and major vector of local and cross-border pollution propagation, as a vital resource of life support, water quality monitoring has gone through many stages in terms of organization and implementation.

The main anthropogenic sources of pollution from the monitored sections of Jiu River were identified and their impact on the quality of the water was analyzed. As shown in the present study, the main sources of pollution are industrial and agricultural activities, followed by wastewater discharged into the Jiu River without proper treatment.

From the present study, carried out on the Jiu River, the water quality in Dolj County on the Răcari - Gângiova sector, a series of general conclusions with theoretical and practical significance can be revealed:

1. Considering the total phosphate concentrations and the biochemical oxygen demand, it falls within the third quality class - moderate ecological status.

2. Depending on the concentration of nitrates and coliforms, it falls in the second quality class - good ecological conditions.

3. Depending on the temperature, $\mathrm{pH}$ and dissolved oxygen it falls into the first quality class - very good environmental status.

4. Based on the importance of the analyzed quality parameters, we believe that Jiu River should be classified in the third quality class (or $\mathrm{C}$ according to the WQI methodology).
Analyzing through the Water Quality Index, all three points show that the water has a medium quality, and therefore the overall quality of Jiu River on the analyzed sector is medium.

In other words, both methods used to determine the quality of the Jiu River in Dolj County led to the same result, namely medium-quality water.

This highlights that it is absolutely necessary to implement urgent measures to bring the Jiu River to a higher quality level, in line with the European objectives in the field, namely to ensure at least a good ecological potential. In order to achieve this goal, the authors recommend:

- Connection of households to sewage and treatment systems to prevent river pollution by domestic wastewater drainage, directly into the river and pollution of the groundwater through infiltration into the soil;

- Ensuring efficient systems for evacuation of rainwater and waste water;

- Increase the efficiency of operation of sewage systems and wastewater treatment plants;

- Apply less polluting and/or more water-efficient technological processes, save water through recycling, and in some cases - extract useful substances from waste water and sediments and avoid waste and/or losses of water;

- Progressively reduce discharges of priority substances and priority hazardous substances (including the total exclusion of priority hazardous waste discharges).

The authors would like to thank the Jiu - Craiova Water Basin Administration for performing the instrumental and chemical analyses and providing the data regarding the quality parameters of Jiu River during 2019.

\section{References}

1. Directive 2000/60/EC of the European Parliament and Council establishing a framework for action for the countries of the European Union in the field of water policy, Official Journal of the European Communities (Bruxelles, 2000) 
2. F. Faur, I.M. Nyari (Apostu), M. Lazăr, Res. J. of Agric. Sci. 49(4), 118-127 (2017)

3. M. Lazăr, 2001, Gospodărirea apelor de suprafață (Surface water management), (Universitas, Petrosani, 2001), p. 200

4. P.J. Chapman, P. Kay, G. Mitchell, C.S. Pitts, Surface water quality, in Water Resources, an Integrated Approach, 2nd edn., ed. by J. Holden, (Routledge, London, 2019), p. 480

5. W. Dodds, M. Whiles, 2019, Freshwater ecology. Concepts \& Environmental Applications of Limnology, 3rd edn., (Academic Press, Cambridge, Massachusetts, 2019), p. 998

6. Romanian Waters National Administration, National Management Plan 2016 - 2021 for Danube and the 11 hydrographic basins/spaces (Bucharest, 2016)

7. Romanian Waters National Administration, Craiova Branch, Report - Management Plans of the Jiu Hydrological Basin in 2016 (Craiova, 2017)

8. A. Vadineanu, R.S. Vadineanu, S. Cristofor, M.C. Adamescu, C. Cazacu, C. Postoloache, G. Risnoveanu, G. Ignat, Scientific arguments for identification of the Lower Danube River System (LDRS) as "Heavily Modified Water Body" (HMWB), Proceedings of the 6th Symposium for European Freshwater Sciences, Sinaia, 2009

9. P. Gâștescu, Water resources in Romania. Potential, quality, territorial distribution, management, Proceedings of the conference Water resources in Romania. Vulnerability to anthropogenic activities, Târgoviște, 2010

10. M. Bretotean, R. Macalet, A. Tenu, M.T. Munteanu, E. Radu, C. Radu, D. Dragusin, Studies on the correlation of water resource assessment methodologies with DCA 60/2000/EC, INHGA Arch., Bucharest, 2004

11. P. Şerban, A. Galie, 2006, Managementul apelor. Principii şi reglementări Europene (Water management. European principles and regulations), (Tipored, Bucharest, 2006), p.302

12. Directive 2008/1/EC of the European Parliament and Council regarding Integrated Pollution Prevention and Control for EU member states, Official Journal of the European Communities (Bruxelles, 2000)

13. SR ISO 5667-6/2014, Water quality. Part 6 Sampling: Guide for sampling of rivers and streams (Bucharest, 2014)

14. SR EN ISO 5667-1:2007, Water quality. Part 1 Sampling: General guide for establishing sampling programs and techniques (Bucharest, 2007)

15. https://www.google.ro/maps/

16. Order 161/2006 for approval of the Normative regarding the classification of surface water quality in order to establish the ecological state of water bodies (in Romanian), Official Monitor, No. 511 (Bucharest, 2006)

17. R. Solomon, Water Resources Assessment Methodology (WRAM). Impact Assessment and Alternative Evaluation, Contract Report Y-77-1, Vickburb, Mississippi, 1977

18. A. Parparov, K.D. Hambright, Water Qual. Res. J. Can. 42(1), 20-25 (2007). https://doi.org/10.2166/wqri.2007.004

19. A. Lumb, T.C. Sharma, J.F. Bibeault, Water Qual. Expo. Health 3(1), 11-24 (2011). https://doi.org/10.1007/s12403-011-0040-0

20. G.C. Curtis, J. of the Am. Water Res. Assoc. 37(1), 125-137 (2001). https://doi.org/10.1111/j.17521688.2001.tb05480.x

21. A. Parparov, K.D. Hambright, T. Berman, Chapter 34. Water Quality Assessment, in Lake Kinneret. Aquatic Ecology Series, ed. by T. Zohary, A. Sukenik, T. Berman, A. Nishri, vol. 6, (Springer, Dordrecht, 2014). https://doi.org/10.1007/978-94017-8944-8 34 